\title{
Work in pregnancy and birth weight for gestational
} age

\author{
B G ARMSTRONG, A D NOLIN, A D McDONALD
}

From the School of Occupational Health, McGill University, 1130 Pine Avenue West, Montreal, Quebec, Canada H3A 1 A3

ABSTRACT In a recent report on prematurity and work in pregnancy based on the Montreal survey noteworthy increases in both preterm births ( $<37$ weeks) and infants of low birth weight $(\leqslant 2500 \mathrm{~g})$ ¿ $_{\rightarrow}$ were found in women in certain specific occupations or whose work entailed heavy lifting, shift work, $\omega$ long hours, or great fatigue. Because of the large overlap between preterm births and low birth weight, $\overrightarrow{0}$ the latter was further analysed with allowance for gestational age in order better to separate factors $\%$ retarding fetal growth from those shortening gestation. The association of low birth weight with ${ }_{-}^{\circ}$ specific occupations, long working hours, and fatigue largely disappeared, suggesting that the effect $\vec{z}$ of these factors was to shorten gestation. By contrast, the association with lifting heavy weights and with shift work persisted, suggesting that these factors retarded fetal growth as well as increasing the? risk of preterm birth.

An analysis of prematurity in a large study carried out in Montreal showed associations of preterm birth ( $<37$ weeks gestation) and low birth weight ( $\leqslant 2500 \mathrm{~g}$ ) with certain occupations, and with lifting heavy weights, long hours of work, and shift work. ${ }^{1}$ Because reduced gestational period is a cause of low birth weight, it was not possible to distinguish factors associated with a shortened gestation period from those associated with retarded fetal growth. A further analysis was therefore undertaken with results reported here.

\section{Methods}

As in the previous analyses of prematurity the study population included 22761 single live births to Montreal women who had worked in similar conditions for $\mathbf{3 0}$ or more hours a week from conception until they left or reached the 28th week. This was reduced to 22404 after excluding women for whom either birth weight or gestational age was unknown. Details of the study design and methods have been described previously. ${ }^{12}$

A statistical method was adopted that allowed parallel analyses of birth weight with and without allowance for gestational age and which permitted comparison with previous analyses. The birth weight in each pregnancy was expressed as per cent of

Accepted 29 February 1988 predicted, the latter accounting for eight non occupational factors; age, gravidity, previous spon taneous abortion, ethnic group, height, educationa level, cigarette smoking, and alcohol consumption $\frac{}{\mathbb{Q}}$ This was achieved by using coefficients obtained from? a preliminary analysis of variance of birth weight in al $\overrightarrow{\mathrm{B}}$ 22404 working women in the study. A second predic tion of birth weight, accounting also for gestationa age, was calculated using regression coefficients of polynomial terms of gestational age up to the cubic entered as covariates in another analysis of variance 3 Table 1 shows the results of these two preliminary analyses.

The relation of birth weight and weight for age with occupational factors was examined by comparing means of the two indices-per cent predicted birtl? weight and weight for age-in specific groups. Test\$ for heterogeneity of means between groups were. carried out using analyses of variance; confidencê intervals for group means were calculated using standard errors derived from the within group mears sum of squares.

\section{Results}

Table 2 shows mean per cent predicted birth weights and weights for age by occupational sector. The meano per cent predicted birth weights were significantly heterogeneous $(p<0.001)$, with those in the health and the manufacturing sectors lowest. Variation o $\overrightarrow{\mathbb{B}}$ 
Table 1 Association of birth weight with potentially confounding variables and gestational age

\begin{tabular}{|c|c|c|c|c|c|}
\hline \multirow[b]{2}{*}{ Factor } & \multirow[b]{2}{*}{ Group } & \multicolumn{2}{|c|}{ Confounding variables only } & \multicolumn{2}{|c|}{$\begin{array}{l}\text { Confounding variables and } \\
\text { gestational age }\end{array}$} \\
\hline & & $\begin{array}{l}\text { Significance } \\
\text { level of } \\
\text { factor* }\end{array}$ & $\begin{array}{l}\text { Difference of } \\
\text { mean from } \\
\text { overall mean } \dagger\end{array}$ & $\begin{array}{l}\text { Significance } \\
\text { level of } \\
\text { factor }\end{array}$ & $\begin{array}{l}\text { Difference of } \\
\text { mean from } \\
\text { overall mean }\end{array}$ \\
\hline Age of mother (y) & $\begin{array}{l}<20 \\
20-29 \\
\geqslant 30\end{array}$ & $p=0.013$ & $\begin{array}{r}57 \\
4 \\
-14\end{array}$ & $p=0.003$ & $\begin{array}{r}72 \\
0 \\
-5\end{array}$ \\
\hline Gravidity & $\begin{array}{l}1 \\
2 \\
3 \\
\geqslant 4\end{array}$ & $\mathrm{p}<0.001$ & $\begin{array}{r}-34 \\
44 \\
79 \\
85\end{array}$ & $\mathrm{p}<0.001$ & $\begin{array}{r}-49 \\
64 \\
111 \\
132\end{array}$ \\
\hline Previous spontaneous abortion & $\begin{array}{l}\text { No } \\
\text { Yes }\end{array}$ & $\mathrm{p}<0.001$ & $\begin{array}{r}12 \\
-81\end{array}$ & $\mathrm{p}<0.001$ & $\begin{array}{r}11 \\
-76\end{array}$ \\
\hline Education of mother & $\begin{array}{l}\text { Primary } \\
\text { Secondary } \\
\text { College }\end{array}$ & $p=0.004$ & $\begin{array}{r}-7 \\
-12 \\
13\end{array}$ & $p>0.1$ & $\begin{array}{r}6 \\
-6 \\
6\end{array}$ \\
\hline Ethnicity & $\begin{array}{l}\text { White: Anglophone } \\
\text { : Francophone } \\
\text { Black } \\
\text { Other and unknown }\end{array}$ & $\mathrm{p}<0.001$ & $\begin{array}{r}69 \\
-2 \\
-117 \\
-57\end{array}$ & $\mathrm{p}<0.001$ & $\begin{array}{r}44 \\
-3 \\
-44 \\
-34\end{array}$ \\
\hline Smoking & $\begin{array}{l}\text { Nil } \\
1-19 \text { cigs daily } \\
\geqslant 20 \text { cigs daily }\end{array}$ & $\mathrm{p}<0.001$ & $\begin{array}{r}72 \\
-117 \\
-178\end{array}$ & $\mathrm{p}<0.001$ & $\begin{array}{r}61 \\
-90 \\
-162\end{array}$ \\
\hline Alcohol & $\begin{array}{l}\text { None } \\
1-2 \text { drinks/week } \\
\geqslant 3 \text { drinks/week }\end{array}$ & $p=0.004$ & $\begin{array}{r}-7 \\
23 \\
2\end{array}$ & $p>0.1$ & $\begin{array}{r}-1 \\
6 \\
-5\end{array}$ \\
\hline Height of mother $(\mathrm{cm})$ & $\begin{array}{l}\leqslant 157 \\
158-164 \\
\geqslant 165\end{array}$ & $\mathrm{p}<0.001$ & $\begin{array}{r}-105 \\
14 \\
92\end{array}$ & $\mathrm{p}<0.001$ & $\begin{array}{r}-92 \\
12 \\
81\end{array}$ \\
\hline Gestational age $\ddagger$ & $\begin{array}{l}\text { Age } \\
\text { Age squared } \\
\text { Age cubed }\end{array}$ & & $\begin{array}{l}- \\
-\end{array}$ & $\begin{array}{l}\mathrm{p}<0.001 \\
\mathrm{p}<0.001 \\
\mathrm{p}<0.001\end{array}$ & $\begin{array}{r}-1342 \cdot 4 \ddagger \\
47 \cdot 3 \ddagger \\
-0.48 \ddagger\end{array}$ \\
\hline
\end{tabular}

*Significance levels of $F$ tests in analysis of variance accounting for all other factors listed.

†Differences in grams of group mean birth weight from overall mean $(3289 \mathrm{~g})$, adjusting for effects of other factors.

†Gestational age entered as a covariate with linear, squared, and cubic terms; regression coefficients shown.

weight for age was not significant $(p>0 \cdot 10)$. Similarly, there was significant variation between the 60 occupational groups for per cent predicted birth weight $(p=0.01)$ but not for weight for age $(p>0 \cdot 10)$. Considered individually, seven of the 60 occupational groups showed deficits in mean per cent predicted birth weights, statistically significant at $\mathrm{p}<0.05$ (one sided test) and an eighth at $\mathrm{p}<0.10$. These results are shown in table 3 together with mean per cent predicted weights for age, only two of which showed significant deficits at $\mathrm{p}<0.05$ and three others at $\mathrm{p}<0 \cdot 10$.

Table 4 shows per cent predicted birth weight and weight for age for work requirements that were significantly associated with low birth weight or preterm birth in our previous analyses. Allowance for possible confounding by undefined selective factors related to occupational sector (not used in the calculation of expected birth weight) was made by entering sector as well as the factor of interest in the analysis of variance. In table 4 the adjusted means are shown. Lifting heavy weights more than 15 times a day and changing shift work were both significantly associated with low birth weight before and after accounting for gestational age. Women working for long hours (46 or more a week) also had lower weight babies than predicted, but this only approached significance when no allowance was made for gestational age.

The fatigue index constructed previously to resemble as closely as possible that used by Mamelle and colleagues $^{3}$ was significantly associated with birth weight $(p=0.03)$ but not with weight for age $(p>0 \cdot 10)$.

Table 2 Mean per cent predicted birth weight and birth weight for age by occupational sector

\begin{tabular}{lccl}
\hline Sector & $\begin{array}{l}\text { No of } \\
\text { pregnancies }\end{array}$ & $\begin{array}{l}\text { Per cent predicted } \\
\text { birth weight }\end{array}$ & $\begin{array}{l}\text { Per cent predicted } \\
\text { weight for age } \\
(90 \% \text { CI) }\end{array}$ \\
\hline Managerial & 4190 & $100 \cdot 8(100 \cdot 4-101 \cdot 2)$ & $100 \cdot 4(100 \cdot 0-100 \cdot 8)$ \\
Health & 2767 & $99 \cdot 4^{* *}(98 \cdot 9-99 \cdot 9)$ & $99.6 *(99 \cdot 1-100 \cdot 1)$ \\
Clerical & 9814 & $100 \cdot 1(99 \cdot 8-100 \cdot 4)$ & $100 \cdot 0(99 \cdot 7-100 \cdot 3)$ \\
Sales & 1190 & $100 \cdot 3(99 \cdot 5-101 \cdot 1)$ & $100 \cdot 4(99 \cdot 6-101 \cdot 2)$ \\
Services & 1692 & $99 \cdot 8(99 \cdot 1-100 \cdot 5)$ & $100 \cdot 4(99 \cdot 8-101 \cdot 0)$ \\
Manufacture & 2706 & $99 \cdot 1 * *(98 \cdot 6-99 \cdot 6)$ & $99 \cdot 7(99 \cdot 2-100 \cdot 2)$ \\
Total & 22404 & $100 \cdot 0$ & $100 \cdot 0$
\end{tabular}

Significance levels of difference from 100 (one sided tests) indicated according to the key: ${ }^{*} p<0.1 ;{ }^{* *} p<0.05 ;{ }^{* * *} p<0.01$. 
Table 3 Mean per cent predicted birth weight and birth weight for age for occupations showing significant deficits (out of $60 \frac{3}{\mathbb{Q}}$ groups)

\begin{tabular}{|c|c|c|c|}
\hline Occupation $\uparrow$ & $\begin{array}{l}\text { No of } \\
\text { pregnancies }\end{array}$ & $\begin{array}{l}\text { Per cent predicted birth weight } \\
(90 \% \text { CI) }\end{array}$ & $\begin{array}{l}\text { Per cent predicted birth weight } \\
\text { for age }(90 \% \mathrm{CI})\end{array}$ \\
\hline $\begin{array}{l}\text { Health sector: } \\
\text { Nurses ( } 3131-\text { excluding psychiatric and } \\
\text { operating room) } \\
\text { Clerical sector: }\end{array}$ & 896 & $98 \cdot 8^{* *} \quad(97 \cdot 9-99 \cdot 7)$ & $98.9 * *(98 \cdot 0-99 \cdot 7)$ \\
\hline $\begin{array}{l}\text { Clerical workers, not otherwise classified } \\
\text { (4199) }\end{array}$ & 378 & $98 \cdot 4^{* *} \quad(97 \cdot 0-99 \cdot 7)$ & $98 \cdot 8 *(97 \cdot 5-100 \cdot 2)$ \\
\hline $\begin{array}{l}\text { Services sector: } \\
\text { Food \& beverage service }(6123,6125) \\
\text { Child care workers }(6147) \\
\text { Manufacturing sector }(8110-8599,9310-9519) \text { : }\end{array}$ & $\begin{array}{l}534 \\
109\end{array}$ & $\begin{array}{ll}98 \cdot 8 * * & (97 \cdot 6-99 \cdot 9) \\
96 \cdot 7^{* *} & (94 \cdot 1-99 \cdot 3)\end{array}$ & $\begin{array}{l}100 \cdot 6 \quad(99 \cdot 5-101 \cdot 7) \\
97 \cdot 4^{* *}(94 \cdot 9-99.9)\end{array}$ \\
\hline $\begin{array}{l}\text { Food and drink }(10-12) \\
\text { Rubber and plastic }(15-16) \\
\text { Textiles (18-19) } \\
\text { Metal, electrical (29-39) }\end{array}$ & $\begin{array}{r}141 \\
69 \\
174 \\
430\end{array}$ & $\begin{array}{l}97 \cdot 4^{* *}(95 \cdot 2-99 \cdot 7) \\
96 \cdot 6^{* *}(93 \cdot 4-99 \cdot 9) \\
98 \cdot 2^{*}(96 \cdot 2-100 \cdot 3) \\
96 \cdot 8^{* * *}(95 \cdot 4-98 \cdot 0)\end{array}$ & $\begin{array}{ll}98 \cdot 2 * & (96 \cdot 0-100 \cdot 4) \\
98 \cdot 5 & (95 \cdot 4-101 \cdot 6) \\
98 \cdot 2^{*} & (96 \cdot 2-100 \cdot 2) \\
99 \cdot 8 & (98 \cdot 6-101 \cdot 1)\end{array}$ \\
\hline
\end{tabular}

${ }^{*} \mathrm{p}<0.1 ;{ }^{*} \mathrm{p}<0.05 ; * *{ }^{*} \mathrm{p}<0.01$. †Four digit Standard Occupational Classification (Ottawa, Statistics Canada 1980) and for the manufacturing sector Standard Industrial Classification (Ottawa, Statistics Canada 1980) given in parentheses.

\section{Discussion}

In the present report mean indices of birth weight are presented rather than risk of birth weight below $2500 \mathrm{~g}$ as in our previous report. ${ }^{12}$ Whereas this form of analysis makes maximum use of information, and allows for gestational age to be taken into account simply, results are less directly interpretable than estimates of risk. The differences between groups in mean per cent predicted birth weight for age were small (1-2\%), even when statistically significant. The approximate relation of these indices to relative risks may be estimated from the observed standard deviation of per cent predicted birth weight, assuming the distributions to be normal. For example, in tables 2,3 , and 4 mean per cent predicted birth weights of $99 \%$, $98 \%$, and $97 \%$ would correspond to relative risks of about $1 \cdot 14,1 \cdot 29$, and $1 \cdot 46$, respectively. Interpreted in this way, the mean per cent predicted birth weights (not accounting for gestational age) in this analysis agree broadly with those for risk of low birth weight reported previously. ${ }^{.}$There are some differences in the specific occupations found at significantly increased risk as would be expected from random variation if small groups.

Whereas low birth weight (not accounting fo gestational age) may reflect short gestations as well as low fetal growth rate, associations of a factor with low birth weight for age is more likely to reflect the lattero To the extent that gestational age is measured imprees cisely this would leave some "residual confounding"; by gestational age, so that even low weight for age could in part reflect the effect of short gestation. The magnitude of this effect, however, would be small.

The pattern of association of birth weight with non occupational confounders (table 1) changed little when gestational age was taken into account, althoug $\overline{\underline{Q}}$ the magnitude of effect varied appreciably for gravidity. Except for gravidity, the same patterns of risk were apparent for preterm births in the previous analysis, ${ }^{1}$ suggesting that several of the confounderê affect both gestational age and fetal growth.

The absence of significant heterogeneity of predic ted weights for age in occupational sectors and specific. occupations suggest that raised risks of low birth weight were more likely to have resulted from shork

Table 4 Mean per cent predicted birth weight and birth weight for age by work requirements

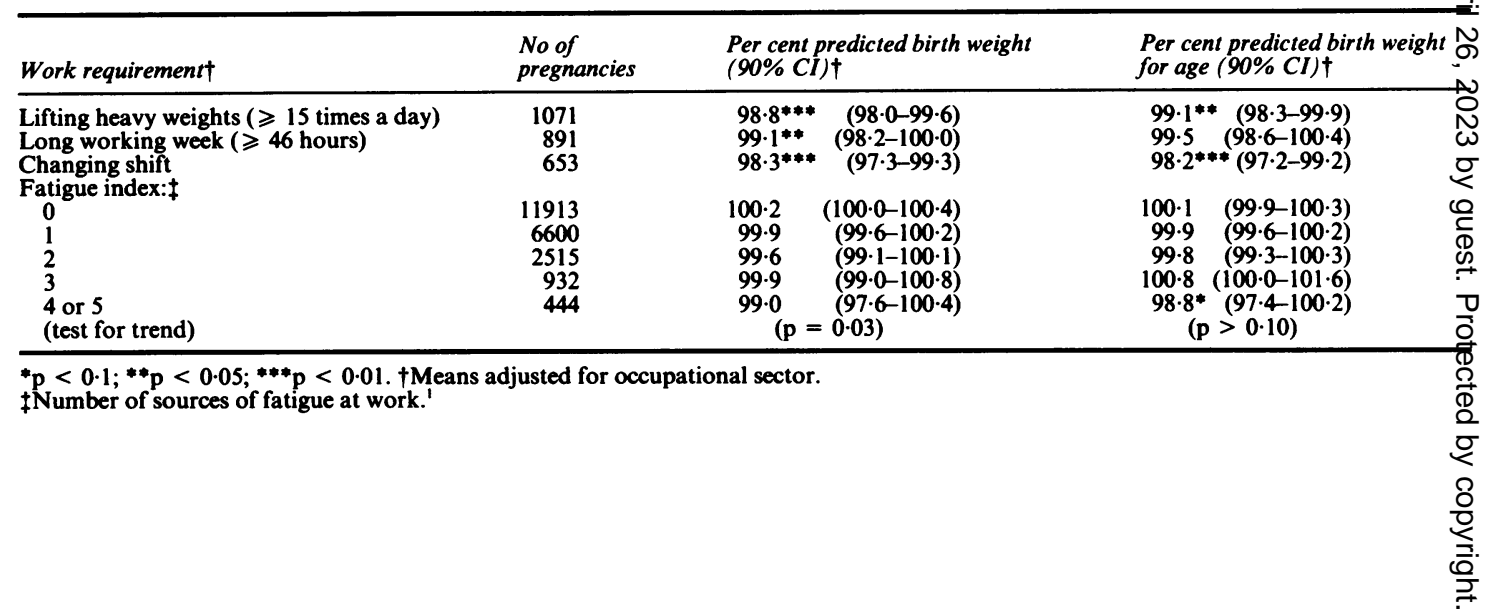


gestations than retarded fetal growth.

The association of low birth weight with heavy lifting remained essentially the same after accounting for gestational age, indicating an effect on fetal growth as well as preterm birth (which was found associated with heavy lifting previously'). Changing shift work was also associated with weight for age (and therefore with fetal growth) and with preterm birth though not significantly. ${ }^{1}$ On the other hand, the association of low birth weight with long working hours diminished on accounting for gestational age and that with the fatigue index disappeared, suggesting that these factors (which showed clear associations with preterm births ${ }^{1}$ ) mainly affect gestational age and not fetal growth rate.

The data for this study were collected as part of a study carried out by one of us (ADMcD) for the Institut de recherche en santé et en sécurité du travail du Québec, who also support BGA through their funding of the Associated Research Team in Occupational Epidemiology.

\section{References}

1 McDonald AD, McDonald JC, Armstrong BG, Cherry NM, Nolin AD, Robert D. Prematurity and work in pregnancy. $\mathrm{Br} J$ Ind Med 1988;45:56-62.

2 McDonald AD, McDonald JC, Armstrong B, et al. Occupation and outcome of pregnancy. Br J Ind Med 1987;44:521-6.

3 Mamelle N, Laumon B, Lazar P. Prematurity and occupational activity during pregnancy. Am J Epidemiol 1984;119:309-22.

4 Greenland $S$. The effect of misclassification in the presence of covariates. Am J Epidemiol 1980;112:564-9.

\section{Correspondence and editorials}

The British Journal of Industrial Medicine welcomes correspondence relating to any of the material appearing in the journal. Results from preliminary or small scale studies may also be published in the correspondence column if this seems appropriate. Letters should be not more than 500 words in length and contain a minimum of references. Tables and figures should be kept to an absolute minimum. Letters are accepted on the understanding that they may be subject to editorial revision and shortening.

The journal now also publishes editorials which are normally specially commissioned. The Editor welcomes suggestions regarding suitable topics; those wishing to submit an editorial, however, should do so only after discussion with the Editor. 